\title{
Studies on Sensitivity of Blackgram (Vigna mungo (L.) Hepper) Varieties to Physical and Chemical Mutagens under in-vitro Condition
}

\author{
M. S. Devi ${ }^{1 *}$, D. M. $\operatorname{Reddy}^{2}$, K. H. P. Reddy ${ }^{1}$, V. L. N. Reddy ${ }^{1}$, \\ D. L. Reddy ${ }^{1}$ and P. Sudhakar ${ }^{3}$
}

${ }^{1}$ Department of Genetics and Plant Breeding, S. V. Agricultural College, ANGRAU, Tirupati-517 502, India

${ }^{2}$ Regional Agricultural Research Station, ANGRAU, Tirupati, India

${ }^{3} A N G R A U$, Lam, Guntur, India

*Corresponding author

\section{A B S T R A C T}

\section{Keywords}

Blackgram, Mutagen, Probit analysis, Gamma rays, EMS, MH and $\mathrm{LD}_{50}$ value

\section{Article Info}

Accepted:

20 July 2020

Available Online:

10 August 2020
The present investigation was taken up to study the sensitivity of two blackgram varieties viz., LBG 752 and TBG 104 to three mutagens on biological parameters and to determine the lethal dose $\left(\mathrm{LD}_{50}\right)$ of mutagens. The seeds were treated with different doses/concentrations of gamma rays (200 Gy, $300 \mathrm{~Gy}, 400 \mathrm{~Gy}, 500 \mathrm{~Gy}$ and $600 \mathrm{~Gy}$ ), EMS (Ethyl methane sulphonate) $(0.2 \%, 0.3 \%, 0.4 \%, 0.5 \%$ and $0.6 \%)$ and $\mathrm{MH}$ (Maleic Hydrazide) $(0.01 \%, 0.02 \%$ and $0.03 \%)$. $\mathrm{MH}$ treatment resulted in drastic reduction in seed germination percentage, shoot length and root length followed by EMS treatment and gamma rays treatment in both the varieties. The reduction in these characters with increasing dose/concentration of mutagens was more prominent in LBG 752 than TBG 104 indicating more sensitive response of LBG 752 to mutagen treatment than TBG 104. $\mathrm{LD}_{50}$ values were estimated based on seed germination percentage and the values were 500.16 Gy for gamma rays, $0.396 \%$ for EMS and $0.016 \%$ for MH in LBG 752 and 552.92 Gy for gamma rays, $0.554 \%$ for EMS and $0.028 \%$ for MH in TBG 104. These findings would greatly help for cost effective selection of variety and mutagens for successful generation of variation in mutation breeding programmes aimed at blackgram crop improvement.

\section{Introduction}

Blackgram (Vigna mungo (L.) Hepper) $(2 \mathrm{n}=22)$ popularly known as urdbean, belongs to family Fabaceae. It is highly nutritious crop rich in seed protein content (24-28 per cent) and contributes 76 per cent carbohydrate, 3 to 5 per cent fibre, 1.74 per cent fat, vitamins like thiamine (B1), riboflavin (B2) and niacin
(B3) and also rich in minerals like phosphorus, calcium, magnesium and potassium etc. (Elangaimannan et al., 2008). This crop has an important role in meeting the dietary protein requirement, in particular, in South India where its products are daily used in different forms like idli, dosa and vada etc. The perusal of the statistics of blackgram showed that India is the largest producer in 
the world with an area of 5.28 million hectares with a production potential of 3.49 million tonnes and a productivity of $662 \mathrm{~kg}$ $\mathrm{ha}^{-1}$ (Indiastat, 2017 - 18). Among the pulses, blackgram ranks fourth in area and production after chickpea, pigeonpea and mungbean and is one of the most highly prized pulses of India. However, the average yield of blackgram is very low in comparison to major grain legumes like chickpea and pigeonpea. Hence, in view of its growing importance and its suitability to various cropping systems and nitches, the production potential of blackgram crop should be enhanced by developing high yielding genotypes. However, as the genetic variability is very low in this crop due to cleistogamous nature and narrow genetic base among the released cultivars, the progress of breeding programmes is not in pace with the growing demands. As the genetic variability is essential for any crop improvement programme, induced mutagenesis could be one of the viable options to bridge this gap. In order to induce variable mutaions both physical and chemical mutagens are most commonly used in crop plants.

In mutation breeding, the success is highly proportionate to the choice of the genotype and the dose of the mutagen which are directly related to the production of desired mutants. The dose that leads to $50 \%$ lethality $\left(\mathrm{LD}_{50}\right)$ has often been chosen for induction of mutations as the lower dose cannot cause mutation in seeds and the higher dose leads to death of the mutated seeds and other deleterious effects. Hence, understanding the sensitivity of genotypes to the mutagens and also determining the $\mathrm{LD}_{50}$ values of mutagens is highly useful for establishment of mutation breeding programme in a cost effective way.

Therefore, the present investigation was undertaken to study the sensitivity of two different blackgram varieties (LBG 752 and TBG 104) to gamma rays, EMS (Ethyl
Methane Sulphonate) and MH (Maleic Hydrazide) treatments in $M_{1}$ generation by considering the effects of mutagens on traits like germination, shoot length and root length and to determine the $\mathrm{LD}_{50}$ value for different mutagens by probit analysis.

\section{Materials and Methods}

The plant material in the present investigation consisted of two promising blackgram varieties of Andhra Pradesh and Telangana viz., LBG 752 and TBG 104. The seeds of these varieties were irradiated with five different doses of gamma rays viz., $200 \mathrm{~Gy}$, $300 \mathrm{~Gy}, 400 \mathrm{~Gy}, 500 \mathrm{~Gy}$ and $600 \mathrm{~Gy}$ at BARC, Trombay. Similarly, for chemical mutagen treatment, the seeds were treated with five different concentrations viz., $0.2 \%$, $0.3 \%, 0.4 \%, 0.5 \%$ and $0.6 \%$ of EMS and three different concentrations of $\mathrm{MH}$ viz., $0.01 \%, 0.02 \%$ and $0.03 \%$ in the Department of Genetics and Plant Breeding, Sri Venkateswara Agricultural College, Tirupati during kharif, 2017-18. The seeds of both the varieties were soaked for six hours in distilled water before the chemical mutagen treatment. The pre-soaked seeds after removal from the water were placed between folds of blotting paper to remove the water adhered on the surface. Then the seeds were immersed for six hours in the requisite concentration of mutagen with intermittent shaking. To ensure uniform absorption of the mutagen, the volume of the mutagen solution was maintained at a proportion of ten times to that of seed volume. The whole treatment was carried out at room temperature of $23 \pm 1^{0} \mathrm{C}$. Immediately after the completion of treatment duration, the treated seeds were thoroughly washed in running water for half-an-hour. A set of untreated seed served as control. The treated seeds with respective control were kept for germination under in-vitro condition following completely randomized design with three replications to fix $L_{50}$ values for 
different mutagens. Five days after sowing, the seed germination percentage, shoot length and root length were recorded in each and every seedling as follows. The percentage of number of seeds that gave rise to normal seedlings with root and shoot growth from the total number of seeds kept for germination was considered as seed germination percentage. The shoot length was measured from the collar region to the tip of the shoot and the root length was measured from the collar region to the tip of the primary root. The sensitivity of two blackgram varieties for different mutagens was assessed based on the rate of reduction in different characters like seed germination, shoot and root length. Probit analysis (Finney, 1971) based on seed germination was carried out to determine $\mathrm{LD}_{50}$ value.

\section{Results and Discussion}

The data recorded on seed germination, shoot length and root length under in-vitro condition for LBG 752 and TBG 104 mutagen treated population were statistically analysed separately and the details of analysis of variance are furnished in Table 1 and 2 . The analysis of variance indicated significant treatment differences for all the three characters studied in gamma rays, EMS and $\mathrm{MH}$ treated population of both the varieties.

The results on effect of gamma rays, EMS and $\mathrm{MH}$ treatments on biological parameters like seed germination, shoot length and root length in LBG 752 and TBG 104 varieties of blackgram are presented and discussed below (Table 3).

Significant reduction in mean germination percentage than their respective control was observed with increase in dose/concentration of all the mutagens in both the varieties except 200 Gy of gamma rays and $0.2 \%$ of EMS treatments in TBG 104 (Table 3). In gamma rays treatment, the mean seed germination percentage ranged from 38.67 (600 Gy) to 86.67 per cent (200 Gy) in LBG 752 and 45.33 (600 Gy) to 97.67 per cent (200 Gy) in TBG 104 as against 98.33 per cent and 99.33 per cent in their respective control (LBG 752 and TBG 104).

Table.1 Analysis of variance for three characters in $\mathrm{M}_{1}$ generation of LBG 752 under in-vitro condition

\begin{tabular}{|c|l|c|c|}
\hline \multirow{2}{*}{ S. No. } & \multicolumn{1}{|c|}{ Characters } & \multicolumn{2}{|c|}{ Mean sum of squares } \\
\cline { 3 - 4 } & & Treatments (df: 13$)$ & Error $(\mathbf{d f :}$ 28) \\
\hline 1. & Seed germination $(\%)$ & $1721.19 * *$ & 8.05 \\
\hline 2. & Shoot length $(\mathrm{cm})$ & $75.04 * *$ & 3.06 \\
\hline 3. & Root length $(\mathrm{cm})$ & $4.98 * *$ & 0.41 \\
\hline
\end{tabular}

** Significant at $1 \%$ level

Table.2 Analysis of variance for three characters in $\mathrm{M}_{1}$ generation of TBG 104 under in-vitro condition

\begin{tabular}{|l|l|c|c|}
\hline \multirow{2}{*}{ S. No. } & \multicolumn{1}{|c|}{ Characters } & \multicolumn{2}{|c|}{ Mean sum of squares } \\
\cline { 3 - 4 } & & Treatments (df: 13) & Error (df: 28) \\
\hline 1. & Seed germination $(\%)$ & $1274.86^{* *}$ & 10.19 \\
\hline 2. & Shoot length $(\mathrm{cm})$ & $59.12^{* *}$ & 1.64 \\
\hline 3. & Root length $(\mathrm{cm})$ & $5.22^{* *}$ & 0.68 \\
\hline
\end{tabular}

** Significant at $1 \%$ level 
Table.3 Effect of mutagens on biological parameters in $\mathrm{M}_{1}$ generation of LBG 752 and TBG 104 under in-vitro condition

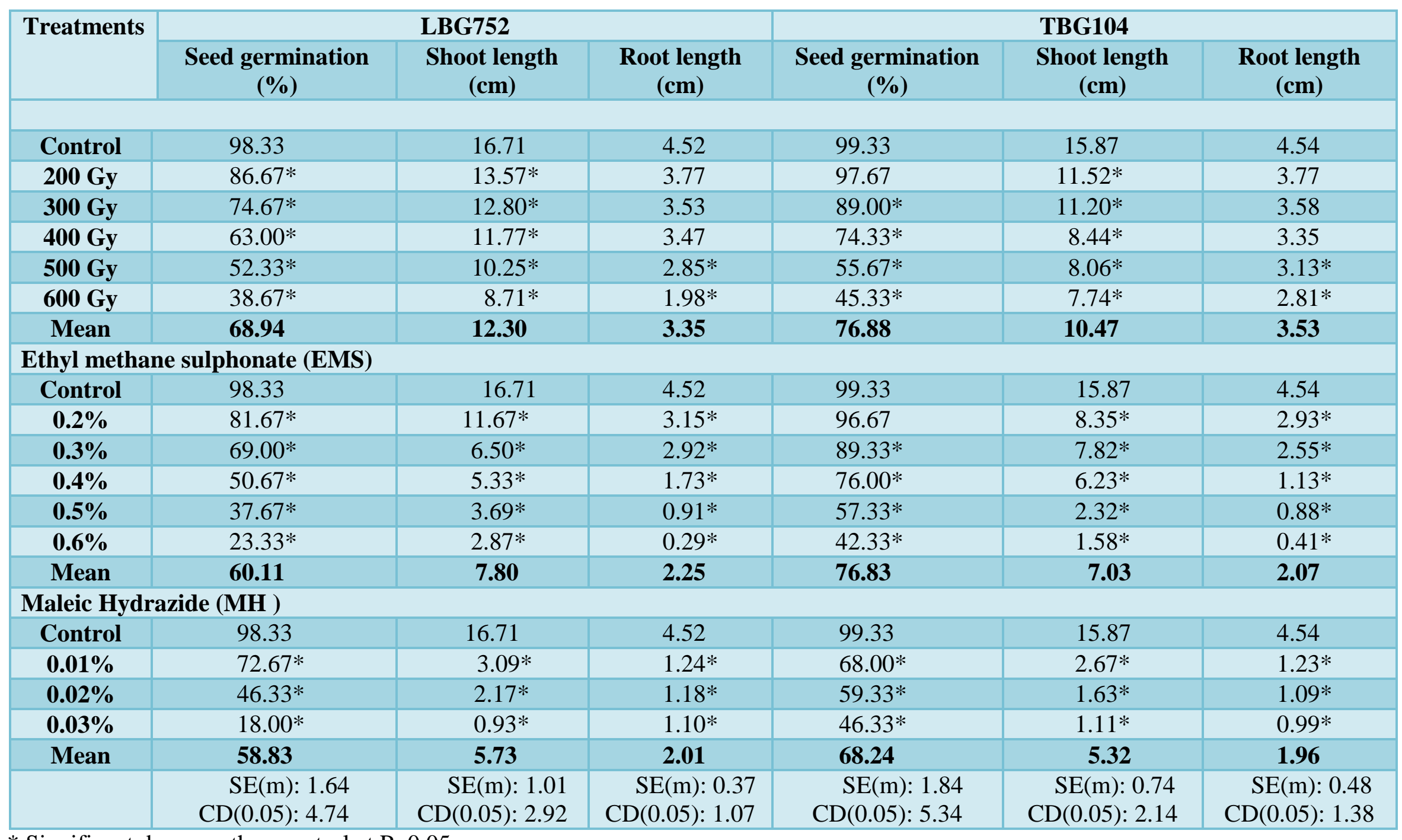

* Significant decrease than control at $\mathrm{P}=0.05$ 
Table.4 Probit analysis for calculating $\mathrm{LD}_{50}$ in gamma rays, EMS and MH treated populations of LBG 752

\begin{tabular}{|c|c|c|c|c|c|c|c|}
\hline & & $\begin{array}{l}\text { Number of } \\
\text { seeds } \\
\text { evaluated }\end{array}$ & $\begin{array}{l}\text { Number of } \\
\text { plants killed }\end{array}$ & $\begin{array}{l}\text { Observed } \\
\text { mortality } \\
\text { percentage }\end{array}$ & $\begin{array}{c}\text { Corrected } \\
\text { mortality } \\
\text { percentage }\end{array}$ & $\begin{array}{c}\log _{10} \text { of } \\
\text { doses }\end{array}$ & $\begin{array}{l}\text { Empirical } \\
\text { probit unit }\end{array}$ \\
\hline \multicolumn{2}{|c|}{ Control } & 75 & 2 & 2.67 & - & - & - \\
\hline \multirow{5}{*}{$\begin{array}{c}\text { Gamma } \\
\text { rays }\end{array}$} & 200 Gy & 75 & 11 & 14.67 & 12.30 & 2.30 & 3.84 \\
\hline & 300 Gy & 75 & 21 & 28.00 & 26.00 & 2.48 & 4.36 \\
\hline & 400 Gy & 75 & 29 & 38.67 & 37.00 & 2.60 & 4.67 \\
\hline & $500 \mathrm{~Gy}$ & 75 & 37 & 49.33 & 47.90 & 2.70 & 4.95 \\
\hline & 600 Gy & 75 & 47 & 62.67 & 61.60 & 2.78 & 5.30 \\
\hline \multirow{5}{*}{$\begin{array}{c}\text { Ethyl } \\
\text { Methane } \\
\text { Sulphonate } \\
\text { (EMS) }\end{array}$} & $0.2 \%$ & 75 & 14 & 18.67 & 16.40 & -0.70 & 4.02 \\
\hline & $0.3 \%$ & 75 & 24 & 32.00 & 30.10 & -0.52 & 4.48 \\
\hline & $0.4 \%$ & 75 & 38 & 50.67 & 49.30 & -0.40 & 4.98 \\
\hline & $0.5 \%$ & 75 & 48 & 64.00 & 63.00 & -0.30 & 5.33 \\
\hline & $0.6 \%$ & 75 & 58 & 77.33 & 76.70 & -0.22 & 5.73 \\
\hline \multirow{3}{*}{$\begin{array}{c}\text { Maleic } \\
\text { Hydrazide } \\
\text { (MH) }\end{array}$} & $0.01 \%$ & 75 & 21 & 28.00 & 26.00 & -2.00 & 4.36 \\
\hline & $0.02 \%$ & 75 & 41 & 54.67 & 53.40 & -1.70 & 5.09 \\
\hline & $0.03 \%$ & 75 & 62 & 82.67 & 82.20 & -1.52 & 5.92 \\
\hline \multicolumn{8}{|c|}{$\mathrm{LD}_{50}$ value for gamma rays $=500.16 \mathrm{~Gy}$} \\
\hline \multicolumn{8}{|c|}{$\begin{array}{ll}\mathrm{LD}_{50} \text { value for } \mathrm{EMS} & =0.396 \% \\
\mathrm{LD}_{50} \text { value for } \mathrm{MH} & =0.016 \%\end{array}$} \\
\hline
\end{tabular}


Table.5 Probit analysis for calculating $\mathrm{LD}_{50}$ in gamma rays, EMS and MH treated populations of TBG 104

\begin{tabular}{|c|c|c|c|c|c|c|c|}
\hline & & $\begin{array}{l}\text { Number of } \\
\text { seeds } \\
\text { evaluated }\end{array}$ & $\begin{array}{l}\text { Number of } \\
\text { plants killed }\end{array}$ & $\begin{array}{c}\text { Observed } \\
\text { mortality } \\
\text { percentage }\end{array}$ & $\begin{array}{c}\text { Corrected } \\
\text { mortality } \\
\text { percentage }\end{array}$ & $\begin{array}{c}\log _{10} \text { of } \\
\text { doses }\end{array}$ & $\begin{array}{c}\text { Empirical } \\
\text { probit unit }\end{array}$ \\
\hline \multicolumn{2}{|c|}{ Control } & 75 & 3 & 4.00 & - & - & - \\
\hline \multirow{5}{*}{$\begin{array}{l}\text { Gamma } \\
\text { rays }\end{array}$} & 200 Gy & 75 & 5 & 6.67 & 2.80 & 2.30 & 3.09 \\
\hline & $300 \mathrm{~Gy}$ & 75 & 9 & 12.00 & 8.30 & 2.48 & 3.62 \\
\hline & 400 Gy & 75 & 21 & 28.00 & 25.00 & 2.60 & 4.33 \\
\hline & 500 Gy & 75 & 35 & 46.67 & 44.40 & 2.70 & 4.86 \\
\hline & 600 Gy & 75 & 43 & 57.33 & 55.60 & 2.78 & 5.14 \\
\hline \multirow{5}{*}{$\begin{array}{c}\text { Ethyl } \\
\text { Methane } \\
\text { Sulphonate } \\
\text { (EMS) }\end{array}$} & $0.2 \%$ & 75 & 7 & 9.33 & 5.60 & -0.70 & 3.41 \\
\hline & $0.3 \%$ & 75 & 15 & 20.00 & 16.70 & -0.52 & 4.03 \\
\hline & $0.4 \%$ & 75 & 22 & 29.33 & 26.40 & -0.40 & 4.37 \\
\hline & $0.5 \%$ & 75 & 33 & 44.00 & 41.70 & -0.30 & 4.79 \\
\hline & $0.6 \%$ & 75 & 45 & 60.00 & 58.30 & -0.22 & 5.21 \\
\hline \multirow{3}{*}{$\begin{array}{c}\text { Maleic } \\
\text { Hydrazide } \\
\text { (MH) }\end{array}$} & $0.01 \%$ & 75 & 24 & 32.00 & 29.20 & -2.00 & 4.45 \\
\hline & $0.02 \%$ & 75 & 32 & 42.67 & 40.30 & -1.70 & 4.75 \\
\hline & $0.03 \%$ & 75 & 41 & 54.67 & 52.80 & -1.52 & 5.07 \\
\hline \multicolumn{8}{|c|}{$\mathrm{LD}_{50}$ value for gamma rays $=552.92 \mathrm{~Gy}$} \\
\hline \multicolumn{8}{|c|}{$\mathrm{LD}_{50}$ value for EMS $\quad=0.554 \%$} \\
\hline
\end{tabular}


Fig.1 Plots of log doses versus probits for calculation of $\mathrm{LD}_{50}$ of gamma rays in $\mathrm{LBG} 752$

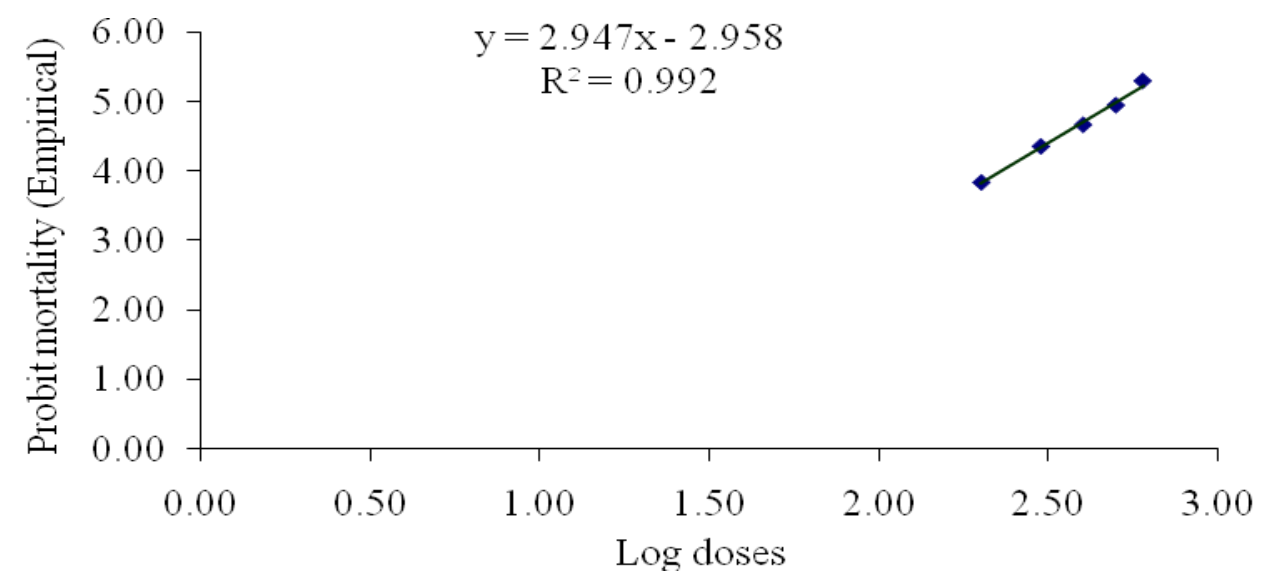

Fig.2 Plots of $\log$ concentrations versus probits for calculation of $\mathrm{LD}_{50}$ of EMS in $\mathrm{LBG} 752$

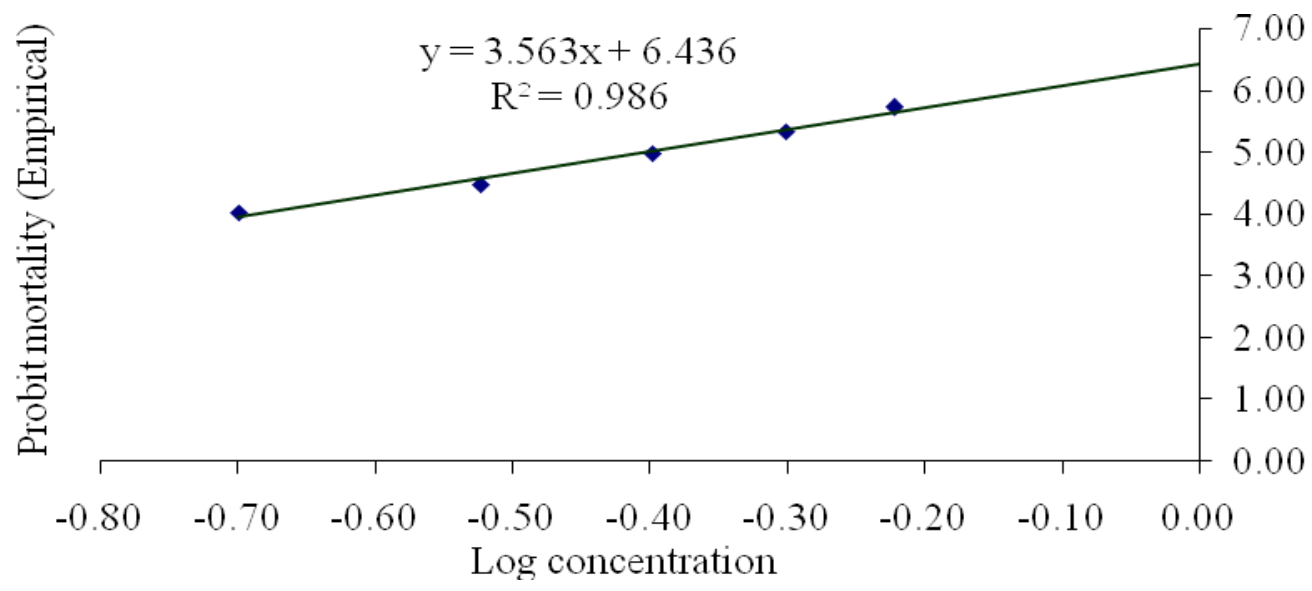

Fig.3 Plots of $\log$ concentrations versus probits for calculation of $\mathrm{LD}_{50}$ of $\mathrm{MH}$ in $\mathrm{LBG} 752$

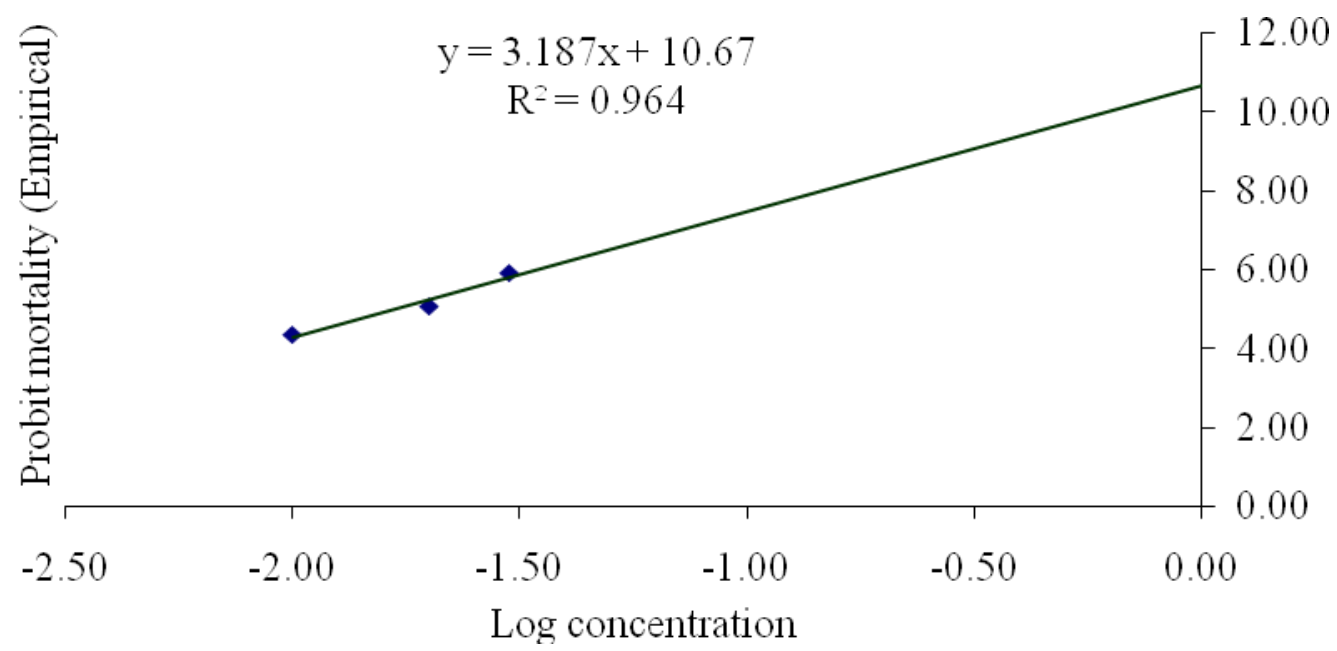


Fig.4 Plots of log doses versus probits for calculation of $\mathrm{LD}_{50}$ of gamma rays in TBG 104

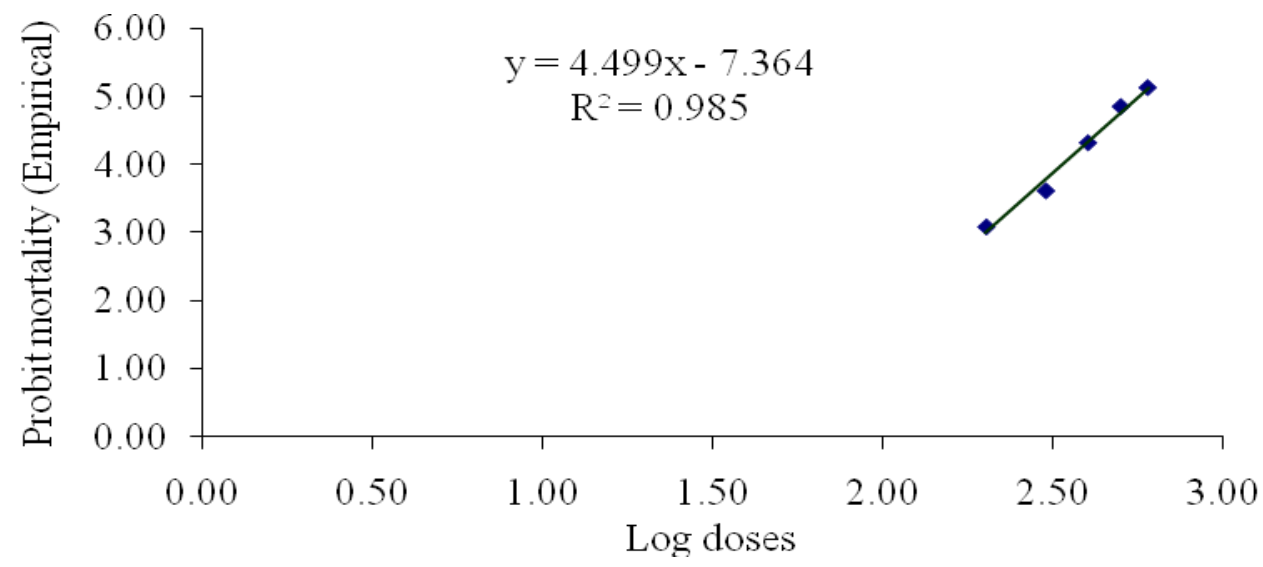

Fig.5 Plots of $\log$ concentrations versus probits for calculation of $\mathrm{LD}_{50}$ of EMS in TBG 104

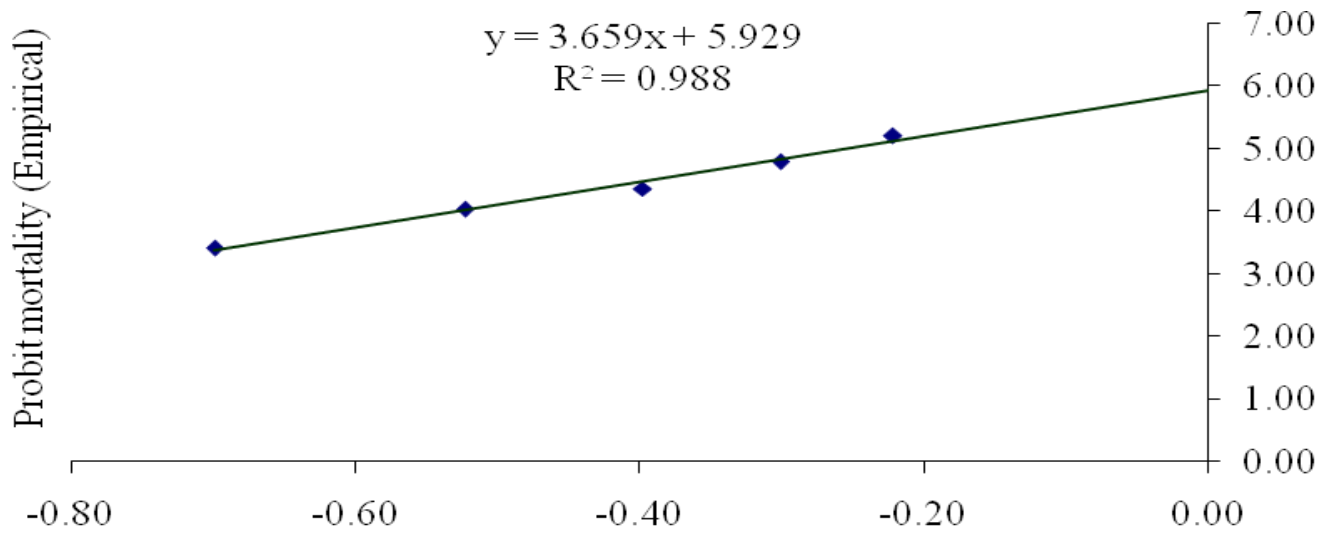

Log concentration

Fig.6 Plots of $\log$ concentrations versus probits for calculation of $\mathrm{LD}_{50}$ of $\mathrm{MH}$ in TBG 104

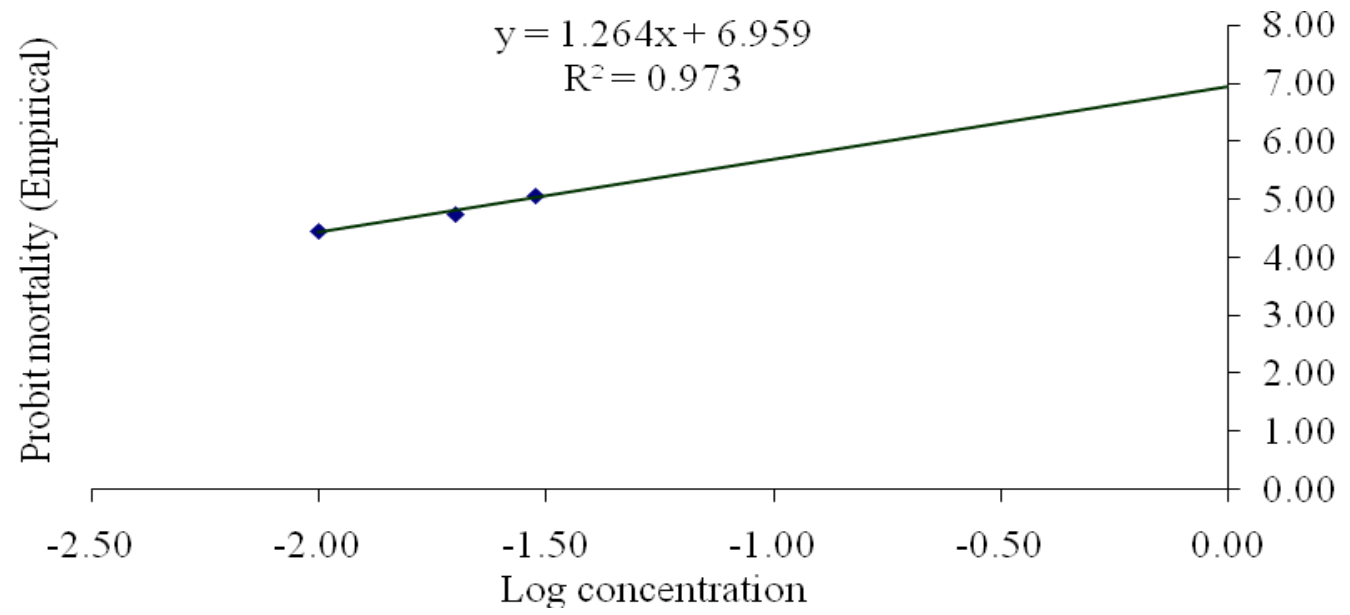


Plate.1 Effect of mutagens on germination, shoot length and root length in M1 generation of LBG 752

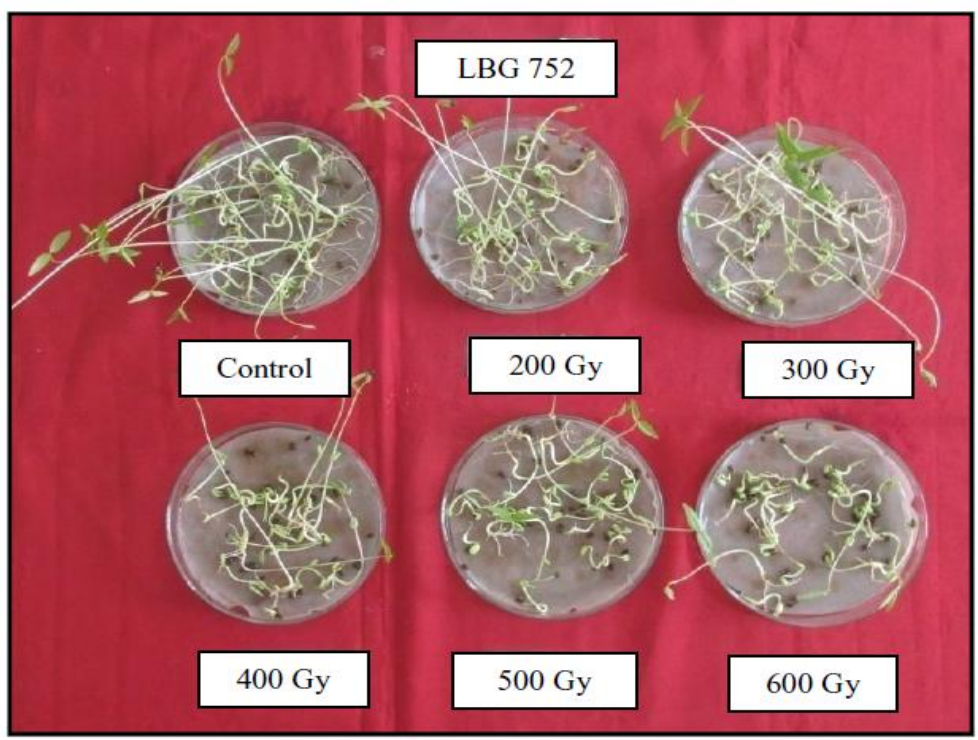

Gamma rays

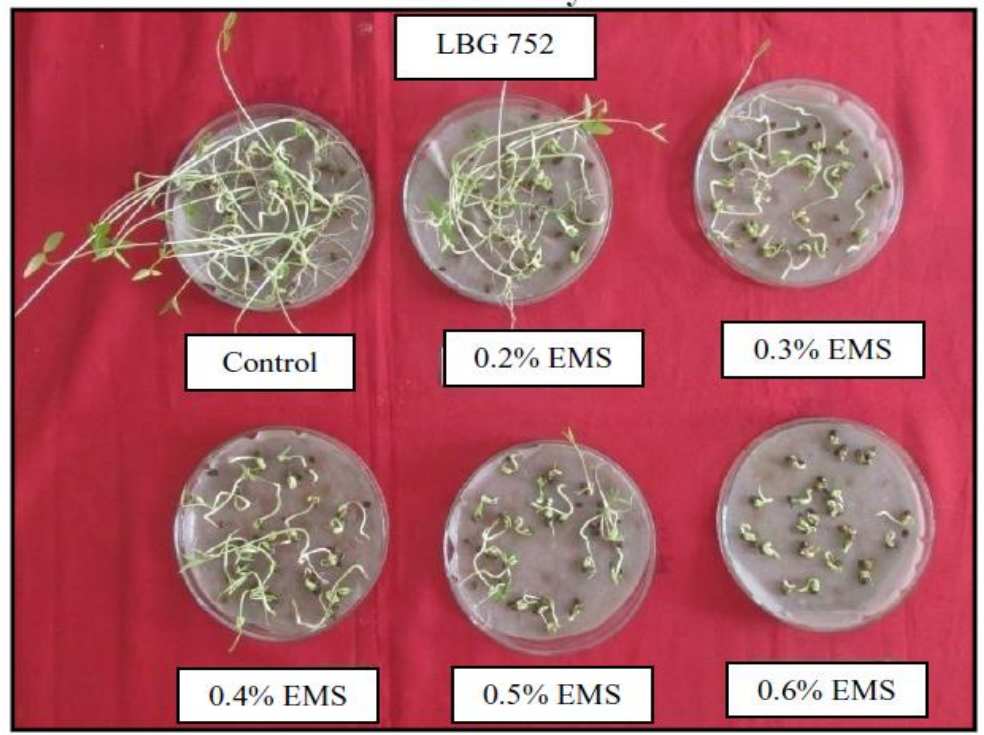

EMS

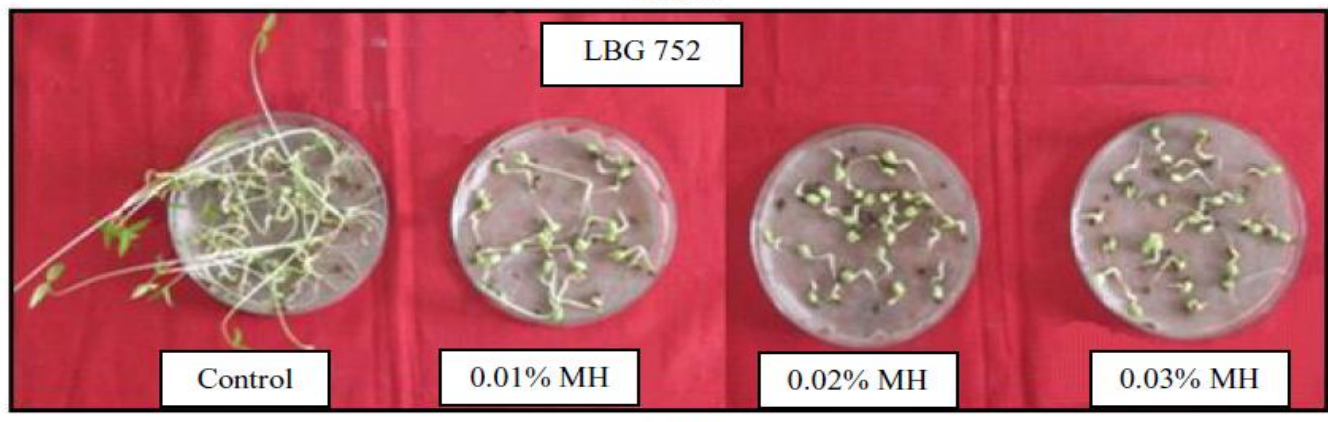

MH 
Plate.2 Effect of mutagens on germination, shoot length and root length in M1 generation of TBG 104

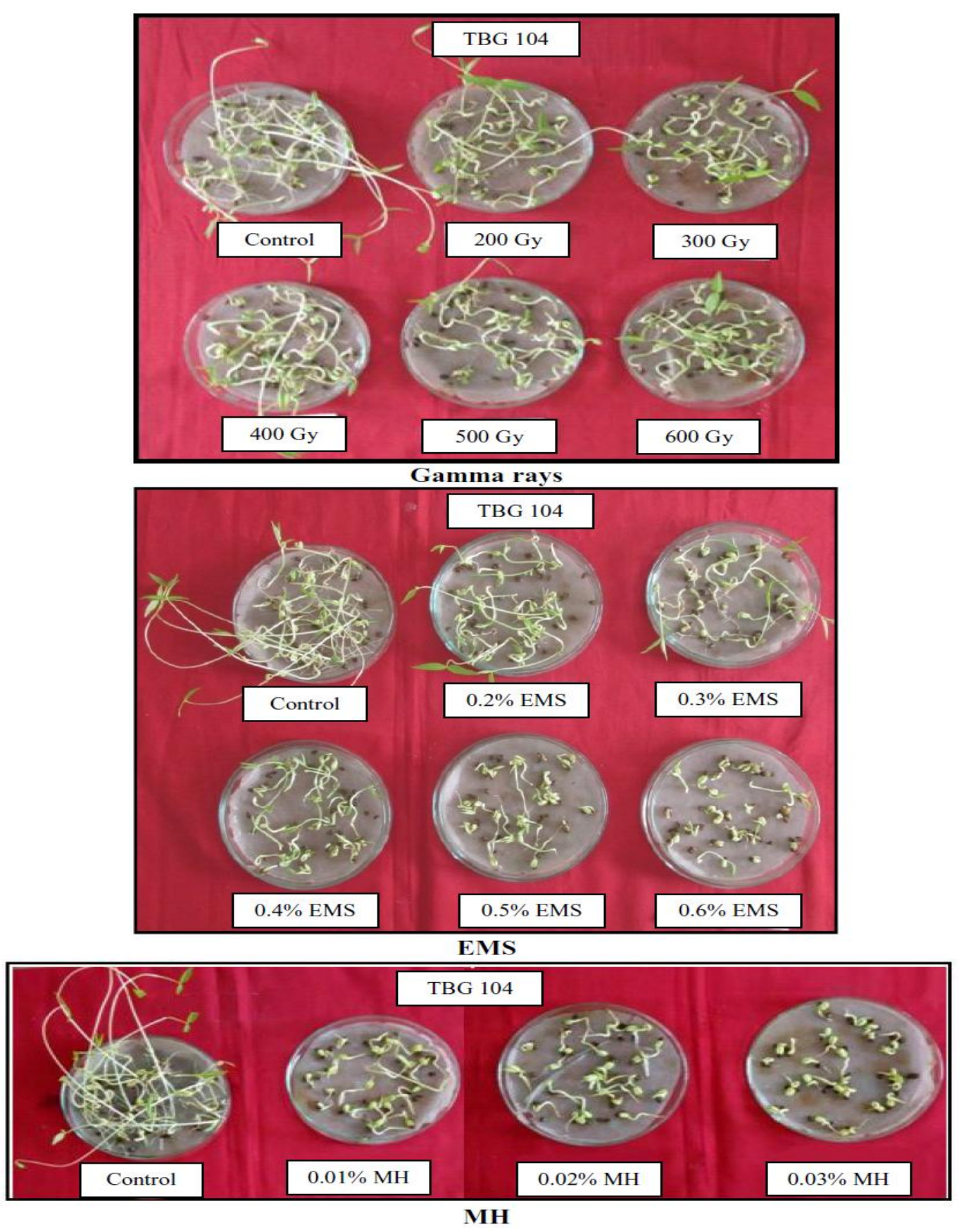

In EMS treatment, germination percentage ranged from $23.33(0.6 \%)$ to 81.67 per cent $(0.2 \%)$ in LBG 752 and $42.33(0.6 \%)$ to 96.67 per cent $(0.2 \%)$ in TBG 104 . Whereas, in $\mathrm{MH}$ treatment seed germination percentage ranged from $18.00(0.03 \%)$ to 72.67 per cent $(0.01 \%)$ in LBG 752 and $46.33(0.03 \%)$ to 68.00 per cent $(0.01 \%)$ in TBG 104 . In LBG 752 , the mean of seed germination in gamma rays, EMS and $\mathrm{MH}$ treated population was $68.94 \%$, $60.11 \%$ and $58.83 \%$, respectively. With respect to TBG 104, the mean of seed 
germination in gamma rays, EMS and $\mathrm{MH}$ treated population was $76.88 \%, 76.83 \%$ and $68.2 \%$, respectively.

Reduction in seed germination percentage due to mutagenic treatment was also reported by Ramya et al., (2014), Dhasarathan et al., (2014) and Usharani et al., (2017) in blackgram. Maherchandani (1975) reported that reduction in germination percentage might be due to the disturbance of promoters and inhibitors balance, probably, in favour of inhibitory materials. In the present investigation, at higher dosage of mutagens, the seed germination got delayed and the seedlings were shorter which subsequently died in short period.

The shoot length in all the treated population of both the varieties was significantly reduced as compared to respective control (Table 3). The shoot length varied from $8.71(600 \mathrm{~Gy})$ to $13.57 \mathrm{~cm}$ (200 Gy) in LBG 752 and 7.74 (600 Gy) to $11.52 \mathrm{~cm}(200 \mathrm{~Gy})$ in TBG 104 in gamma rays treatment; $2.87(0.6 \%)$ to 11.67 $\mathrm{cm}(0.2 \%)$ in LBG 752 and $1.58(0.6 \%)$ to $8.35 \mathrm{~cm}(0.2 \%)$ in TBG 104 in EMS treatments; and $0.93(0.03 \%)$ to $3.09 \mathrm{~cm}$ $(0.01 \%)$ in LBG 752 and $1.11(0.03 \%)$ to 2.67 $\mathrm{cm}(0.01 \%)$ in TBG 104 in $\mathrm{MH}$ treatments as against the values of $16.71 \mathrm{~cm}$ (LBG 752) and $15.87 \mathrm{~cm}$ (TBG 104) of their respective control. In LBG 752, the mean of shoot length in gamma rays, EMS and $\mathrm{MH}$ treated population was $12.30 \mathrm{~cm}, 7.80 \mathrm{~cm}$ and 5.73 $\mathrm{cm}$, respectively. With respect to TBG 104 , the mean of shoot length in gamma rays, EMS and $\mathrm{MH}$ treated population was $10.47 \mathrm{~cm}$, $7.03 \mathrm{~cm}$ and $5.32 \mathrm{~cm}$, respectively.

Regarding the root length, the mean root length recorded was significantly lesser than their respective control in all the mutagen treatments in both the varieties except 200 Gy, 300 Gy and 400 Gy doses of gamma rays treatment (Table 3). The root length ranged from 1.98 (600 Gy) to $3.77 \mathrm{~cm}(200 \mathrm{~Gy})$ in LBG 752 and 2.81 (600 Gy) to $3.77 \mathrm{~cm}$ (200 Gy) in TBG 104 in gamma rays treatment while, in EMS treatments it varied from 0.29 $(0.6 \%)$ to $3.15 \mathrm{~cm}(0.2 \%)$ in LBG 752 and $0.41(0.6 \%)$ to $2.93 \mathrm{~cm}(0.2 \%)$ in TBG 104 . In $\mathrm{MH}$ treatment, the root length ranged from $1.10(0.03 \%)$ to $1.24 \mathrm{~cm}(0.01 \%)$ in LBG 752 and $0.99(0.03 \%)$ to $1.23 \mathrm{~cm}(0.01 \%)$ in $\mathrm{TBG}$ 104 as against the values of $4.52 \mathrm{~cm}$ (LBG752) and $4.54 \mathrm{~cm}$ (TBG 104) of respective control. In LBG 752, the mean of shoot length in gamma rays, EMS and $\mathrm{MH}$ treated population was $3.35 \mathrm{~cm}, 2.25 \mathrm{~cm}$ and $2.01 \mathrm{~cm}$, respectively. With respect to TBG 104 , the mean of shoot length in gamma rays, EMS and MH treated population was 3.53 $\mathrm{cm}, 2.07 \mathrm{~cm}$ and $1.96 \mathrm{~cm}$, respectively. Such reports of reduction in shoot and root length was also reported by Surendar and Vanniarajan (2014), Lavanya et al., (2016), Usharani et al., (2017) and Veni et al., (2017) in blackgram.

In all three mutagen treatments viz., gamma rays, EMS and $\mathrm{MH}$, the seed germination percentage, shoot length and root length were lesser than their respective control and these characters decreased progressively with the increase in doses/concentration of all the mutagens in both the varieties viz., LBG 752 and TBG 104. In the present investigation, the high proportion of seed lethality due to mutagen treatment might be associated with weakening of intra-chromosomal linkage or accumulation of deleterious mutations in different genomes. The reduction in germination might be due to the alkylation of sulphahydral (-SH) group of important proteins causing death of the seeds (Ehrenberg and Lundquist, 1961).

The reduction in shoot and root length could be attributed to the effects of mutagens on the physiological system (Gaul, 1977). According to Rupinder and Kole (2005) severe reduction 
in plumule to radical length and physical injuries of radicles indicated that the root inhibition arises primarily from the effect on meristems by arresting the synthesis of growth stimulating auxins and consequent inhibition of cell division. The influence on shoot and root growth has been related to many factors which may be attributed to chromosomal abnormality with height reduction, reduction in auxin levels, inhibition of auxin synthesis, failure of assimilation mechanism and chromosomal damage cum mitotic inhibition (Riley, 1954).

\section{Probit analysis for determination of $\mathbf{L D}_{50}$ dose of mutagens}

The $\mathrm{LD}_{50}$ values were determined with the help of probit analysis for the physical and chemical mutagens based on seed germination percentage. $\mathrm{LD}_{50}$ value is essential to fix the optimum dose that cause maximum of mutation with minimum of damage to the plant. The $\mathrm{LD}_{50}$ value also helps in knowing the sensitivity of different genotypes to the mutagens. In the present study, probit analysis was carried out in mutagen treated populations of LBG 752 and TBG 104 blackgram varieties to determine $\mathrm{LD}_{50}$ values for gamma rays, EMS and $\mathrm{MH}$ treatments under in-vitro condition. The results obtained on observed mortality percentage for gamma rays, EMS and MH treated population are presented in Tables 4 and 5 (Fig.1 to 6).

Mean observed mortality percentage increased with increase in the dose/concentration of all the mutagen treatments in both the varieties. In LBG 752 variety, the mean mortality percentage of gamma ray treatment increased from 14.67 per cent (200 Gy) to 62.67 per cent (600 Gy) and in TBG 104 variety, it increased from 6.67 (200 Gy) to 57.33 per cent (600 Gy). The mean mortality percentage of EMS treatment increased from 18.67 per cent $(0.2 \%)$ to 77.33 per cent $(0.6 \%)$ in LBG 752 variety and in TBG 104 variety, it increased from 9.33 per cent $(0.2 \%)$ to 60.00 per cent $(0.6 \%)$ of EMS. Whereas, mean observed mortality percentage of $\mathrm{MH}$ treatment increased from 28.00 per cent $(0.01 \%)$ to 82.67 per cent $(0.03 \%)$ in LBG 752 variety and in TBG 104 variety, it increased from 32.00 per cent $(0.01 \%)$ to 54.67 per cent $(0.03 \%)$. Further, the highest mortality percentage was observed at $600 \mathrm{~Gy}$ of gamma ray, $0.6 \%$ of EMS and $0.03 \%$ of $\mathrm{MH}$ treatments in both the varieties. However, between LBG 752 and TBG 104 varieties, highest mortality percentage was recorded in LBG 752 at all the doses.

The $\mathrm{LD}_{50}$ values were $500.16 \mathrm{~Gy}$ for gamma rays, $0.396 \%$ for EMS and $0.016 \%$ for $\mathrm{MH}$ in LBG 752 and 552.92 Gy for gamma rays, $0.554 \%$ for EMS and $0.028 \%$ for $\mathrm{MH}$ in $\mathrm{TBG}$ 104 (Table 5). From the results, it was observed that TBG 104 found to be more tolerant to different mutagen treatments than LBG 752. The differences in the sensitivity of the varieties of blackgram based on $\mathrm{LD}_{50}$ values indicated the differential response of specific genotypes to different mutagens. Such variations were also reported by Surendar and Vanniarajan (2014) in blackgram. However, minor differences were observed in $\mathrm{LD}_{50}$ doses between genotypes by Dhasarathan (2014), Ramya et al., (2014) and Veni et al., (2017) in blackgram.

In conclusion the study on effect of various mutagens on two blackgram viz., LBG 752 and TBG 104 in $M_{1}$ revealed that among all the treatments, $\mathrm{MH}$ treatment resulted in drastic reduction in seed germination percentage, shoot length and root length followed by EMS and gamma rays treatments in both the varieties. It was also clear that the reduction in all these characters with increasing dose/concentration of mutagens was more conspicuous in LBG 752 than TBG 104 indicating more sensitivity of LBG 752 to 
mutagen treatment than TBG 104. These findings would greatly help for cost effective selection of variety and mutagens for successful generation of variation in mutation breeding programmes aimed at blackgram crop improvement.

\section{References}

Dhasarathan, M., Meenakshiganesan, $\mathrm{N}$ and Geetha, S. 2014. Studies on the influence of physical mutagen (gamma irradiation) in black gram (Vigna mungo (L.) Hepper). Life Sciences Leaflets. 56: 1319.

Ehrenberg, L and Lundquist, V. 1961. Viable mutants induced in barley ionizing radiations and chemical mutagens. Hereditas., 47:243-282.

Elangaimannan, R., Anbuselvam, Y and Karthikeyan, P. (2008). Genetic diversity in blackgram [Vigna mungo (L.) Hepper]. Legume Research. 31(1): 57-59.

Finney, D.J. 1971. Probit Analysis ( $3^{\text {rd }}$ edition). Cambridge University Press, London.

Gaul, H. 1977. Mutagen effects observable in the first generation. I. Plant injury and lethality, II. Cytological effects and sterility. Manual on Mutation Breeding $\left(2^{\text {nd }}\right.$ edition), technical report series No. 119, IAEA, Vienna, Austria. Pp. 85-99.

Indiastat, 201718. https://www.indiastat.com/agriculture/2/st ats.aspx

Lavanya, S.A., Vanniarajan, $\mathrm{C}$ and Souframanien, J. 2016. Kill curve analysis and response of first generation blackgram (Vigna mungo (L.) Hepper) cultivars to gamma rays and electron beam radiation. The Bioscan. 11(4): 3133-3138.

Maherchandani, N. 1975. Effects of gamma radiation on the dormant seeds of Avena fatua L. Radiation Botany. 15:439-443.

Ramya, B. Nallathambi, G and Ram, S.R. 2014. The effect of mutagens on $\mathrm{M}_{1}$ population of blackgram (Vigna mungo (L.) Hepper). Academic Journals. 13(8): 951-956.

Riley, E. F. 1954. The effect of X- rays upon growth of Avena seedlings. Radiation Research. 1: 27-228.

Rupinder, S and Kole, C.R. 2005. Effect of mutagenic treatment with EMS on germination and some seedling parameters in mungbean. Crop Reearch. 2(2): 236-240.

Surendar, R and Vanniarajan, C. 2014. Determination of lethal dose and biological injury by gamma rays and ethyl methane sulphonate in $\mathrm{M}_{1}$ generation of blackgram (Vigna mungo (L.) Hepper). Trends in Biosciences. 7(16): 2148-2153.

Usharani, K.S., Kumar, C.R.A and Vanniarajan, C 2017. Fixation of lethal dose 50 and effect of mutagens in $\mathrm{M}_{1}$ generation under laboratory condition. International Journal of Current Microbiology and Applied Sciences. 6(7): 1356-1365.

Veni, K., Vanniarajan, C and Souframanien, J. 2017. Probit analysis and effect of electron beam and gamma rays in blackgram (Vigna mungo (L.) Hepper). Electronic Journal of Plant Breeding. 8(3): 950-955.

\section{How to cite this article:}

Devi, M. S., D. M. Reddy, K. H. P. Reddy, V. L. N. Reddy, D. L. Reddy and Sudhakar, P. 2020. Studies on Sensitivity of Blackgram (Vigna mungo (L.) Hepper) Varieties to Physical and Chemical Mutagens under in-vitro Condition. Int.J.Curr.Microbiol.App.Sci. 9(08): 31613173. doi: https://doi.org/10.20546/ijcmas.2020.908.360 